\title{
Pemberdayaan Kelompok Setia Kawan dalam Produksi Garam Beryodium di Desa Labuhan Bajo, Sumbawa
}

\section{(Setia Kawan Group Empowerment of Labuhan Bajo Sumbawa through Iodized Salt Production)}

\author{
Dedi Syafikri' ${ }^{1}$, Dwi Mardhia ${ }^{*}$, Fahmi Yahya ${ }^{2}$, Nining Andriyani ${ }^{3}$ \\ 1 Program Studi Manajemen Sumberdaya Perairan, Fakultas Peternakan dan Perikanan, Universitas Samawa \\ Jalan Raya Semongkat No. 1 Kampus Bileng Monte, Sumbawa Besar, Nusa Tenggara Barat 84313. \\ 2 Program Studi Pendidikan Fisika, Fakultas Keguruan dan Ilmu Pendidikan, Universitas Samawa \\ Jalan Raya By Pass Sering, Sumbawa Besar, Nusa Tenggara Barat 84313. \\ 3 Program Studi Pendidikan Ekonomi, Fakultas Keguruan dan Ilmu Pendidikan, Universitas Samawa, \\ Jalan Raya By Pass Sering, Sumbawa Besar, Nusa Tenggara Barat 84313. \\ *Penulis Korespondensi: kemang.kuneng@gmail.com \\ Diterima Juli 2019/Disetujui Desember 2019
}

\begin{abstract}
ABSTRAK
Desa Labuhan Bajo merupakan salah satu desa yang ditetapkan sebagai sentra pengembangan garam rakyat di Kabupaten Sumbawa. Permasalahan terkait garam yang dijumpai di Desa Labuhan Bajo adalah masih minimnya pendapatan kelompok petani garam, masih perlu adanya peningkatan kualitas dan kuantitas produksi garam, serta belum adanya produksi garam beryodium. Selain itu, permasalahan terkait gangguan akibat kekurangan yodium (GAKY) salah satunya adalah kasus stunting yang perlu penanganan segera mengingat Desa Labuhan Bajo merupakan salah satu desa di Kecamatan Utan yang memiliki prevelansi stunting yang cukup tinggi. Oleh karena itu, kegiatan pengabdian ini diharapkan dapat menjadi solusi bagi tersedianya produksi garam beryodium di Sumbawa khususnya di Desa Labuhan Bajo sekaligus memberi kontribusi bagi pencegahan stunting. Tujuan dari kegiatan pengabdian ini adalah mendampingi kelompok Setia Kawan dalam meningkatkan kuantitas dan kualitas garam menjadi garam KW 1 dan menghasilkan produksi garam beryodium yang memenuhi persyaratan SNI. Metode pelaksanaan kegiatan pengabdian ini meliputi kegiatan penyuluhan, pelatihan, bantuan pengadaan alat, dan pendampingan. Hasil dari kegiatan ini adalah tersedianya teknologi pengolahan garam menggunakan metode teknologi ulir filter (TUF) dan iodisasi, meningkatnya jumlah produksi garam oleh Kelompok Setia Kawan, tersedianya garam KW 1 dan beryodium, meningkatnya pendapatan kelompok Setia Kawan, meningkatnya jaringan pemasaran dan meningkatnya pengetahuan dan keterampilan kelompok petambak garam dalam menerapkan metode TUF dan iodisasi.
\end{abstract}

Kata kunci: garam beryodium, Labuhan Bajo, stunting

\begin{abstract}
Labuhan Bajo Village is one of the villages designated as a center for the development of community salt in Sumbawa Regency. Problem related to salt encountered in Labuhan Bajo Village is the low income of the salt farmers group, there is still need to increase the quality and quantity of salt production and the absence of iodized salt production. The other problem is related to iodine deficiency (IDD), such as the stunting case, which is need to be handled immediately, considering that Labuhan Bajo Village is one of the villages in Utan Subdistrict which has a high stunted prevalence (22.1\%). Therefore this service is expected to be a solution for the availability of iodized salt production in Sumbawa, especially in Labuhan Bajo Village while contributing to stunted prevention. The aim of this service activity is to assist Setia Kawan group in increasing the quantity and quality of salt to KW 1 and producing iodized salt that meets SNI requirements. The method for carrying out this community service activity includes counseling, training, assistance in procurement of equipment and assistance. The results of this activity are the availability of salt processing technology using the TUF + Iodization method, increasing the amount of salt production by the Setia Kawan Group, the availability of KW 1 salt and iodized, increasing the income of the Setia Kawan group, increasing the marketing network and increasing the knowledge and skills of salt farmers in applying TUF + Iodization method.
\end{abstract}

Keywords: iodized salt, Labuhan Bajo, stunted 


\section{PENDAHULUAN}

Desa Labuhan Bajo terletak di Kecamatan Utan, Kabupaten Sumbawa. Berdasarkan data statistik Kabupaten Sumbawa bahwa Desa Labuhan Bajo memiliki luas tanah kering yang tidak bisa dimanfaatkan untuk kegiatan pertanian, yaitu 1.967 Ha (90\% dari luas wilayah). Ini merupakan potensi untuk mengembangkan desa tersebut sebagai sentra penghasil garam mengingat Kabupaten Sumbawa telah ditunjuk sebagai salah satu daerah penyangga kebutuhan garam Nasional. Selain itu, Desa Labuhan Bajo termasuk salah satu lokasi yang ditetapkan sebagai daerah pengembangan usaha tambak garam (Syafikri 2016). Diharapkan usaha tambak garam akan menjadi salah satu sektor penting dalam menunjang perekonomian daerah.

Saat ini di Desa Labuhan Bajo sudah terdapat empat kelompok petambak garam, yaitu Kelompok Maju Bersama, Angin Mamiri, Setia Kawan dan Garam Keluarga. Kelompok Maju Bersama dan Angin Mamiri terbentuk sejak tahun 2014, sedangkan kelompok Setia kawan dan Garam Keluarga baru terbentuk pada akhir tahun 2017. Kelompok Maju Bersama dan Angin Mamiri termasuk kedalam KUGAR (kelompok usaha garam rakyat) dan sudah mendapat pendanaan dari pemerintah sedangkan kelompok Setia Kawan dan Garam Keluarga bukan bagian dari KUGAR dan belum pernah mendapat bantuan dari pihak manapun (Syafikri 2016). Selama ini, kelompok petambak garam memiliki beberapa permasalahan sehingga menyebabkan usaha kelompok belum berkembang dan belum bisa memberikan hasil yang menjanjikan. Tingkat produktivitas lahan penggaraman di Desa Labuhan Bajo masih perlu ditingkatkan baik kualitas maupun kuantitasnya karena kondisi produksi yang ada saat ini adalah kualitas garam masih tergolong garam KW 2 sehingga memiliki nilai jual yang rendah, yaitu Rp 800/kg. Distribusi dan pemasaran juga menjadi kendala karena selama ini kelompok menjual sendiri garam sehingga dibutuhkan adanya wadah seperti koperasi untuk memasarkan hasil produksi. Permasalahan yang tidak kalah pentingnya adalah kurangnya pengetahuan kelompok terkait teknologi produksi garam yang tepat dan belum adanya pengetahuan tentang produksi garam beryodium. Padahal produksi garam beryodium merupakan peluang besar untuk meningkatkan pendapatan kelompok.

Semua kelompok garam yang ada di Desa Labuhan Bajo belum ada yang menghasilkan garam beryodium (Hidayat \& Syafikri 2014). Permasalahan terkait produksi garam berimplikasi terhadap konsumsi garam pada masyarakat yang berdampak pada rendahnya kualitas kesehatan masyarakat. Gangguan akibat kekurangan yodium (GAKY) merupakan satu dari beberapa masalah serius yang dihadapi, angka kejadian GAKY khususnya stunting di Desa Labuhan Bajo cukup tinggi mencapai angka $22,1 \%$. Upaya penanggulangan GAKY telah dilakukan secara nasional melalui upaya jangka pendek dan jangka panjang, namun dalam pelaksanaannya masih ditemui kendala, yaitu masih minimnya konsumsi garam beryodium oleh masyarakat (Rositawati et al. 2013). Penambahan yodium pada garam konsumsi merupakan cara yang tepat dan efektif mendapatkan hasil maksimum dalam pencapaian konsumsi garam beryodium di masyarakat (Setiawan et al. 2018).

Salah satu bentuk peran perguruan tinggi dalam mengatasi hal tersebut adalah dengan melakukan pemberdayaan kepada kelompok garam sehingga menghasilkan produk garam beryodium yang akan meningkatkan pendapatan masyarakat, namun secara bersamaan memenuhi kebutuhan garam beryodium masyarakat sehingga permasalahan terkait GAKY dan stunting dapat teratasi (Hartati et al. 2014). Tujuan dari kegiatan pengabdian ini adalah mendampingi kelompok Setia Kawan dalam meningkatkan kuantitas dan kualitas garam menjadi garam KW 1 dan menghasilkan produksi garam beryodium yang memenuhi persyaratan $\mathrm{SNI}$ dengan kadar yodium 30-80 ppm. Kegiatan pengabdian ini diharapkan dapat membantu memenuhi kebutuhan garam masyarakat, sehingga meningkatkan jumlah rumah tangga yang mengkonsumsi garam beryodium dan berimplikasi pada penurunan GAKY khususnya angka kejadian stunting.

\section{METODE PELAKSANAAN KEGIATAN}

\section{Waktu, Lokasi, dan Mitra Kegiatan}

Kegiatan pengabdian dalam bentuk Program Pengembangan Desa Mitra (PPDM) dilaksanakan mulai bulan April-Agustus pada tahun 2019. Kegiatan dilaksanakan di Desa Labuhan Bajo, Kecamatan Utan, Kabupaten Sumbawa, Provinsi Nusa Tenggara Barat (Gambar 1). Jarak lokasi mitra dengan perguruan tinggi tim PPDM adalah $\pm 87,7 \mathrm{~km}$. Mitra pada kegiatan ini adalah kelompok Setia Kawan yang merupakan kelompok yang tidak termasuk dalam KUGAR (Kelompok Usaha Garam Rakyat) sehingga perlu 


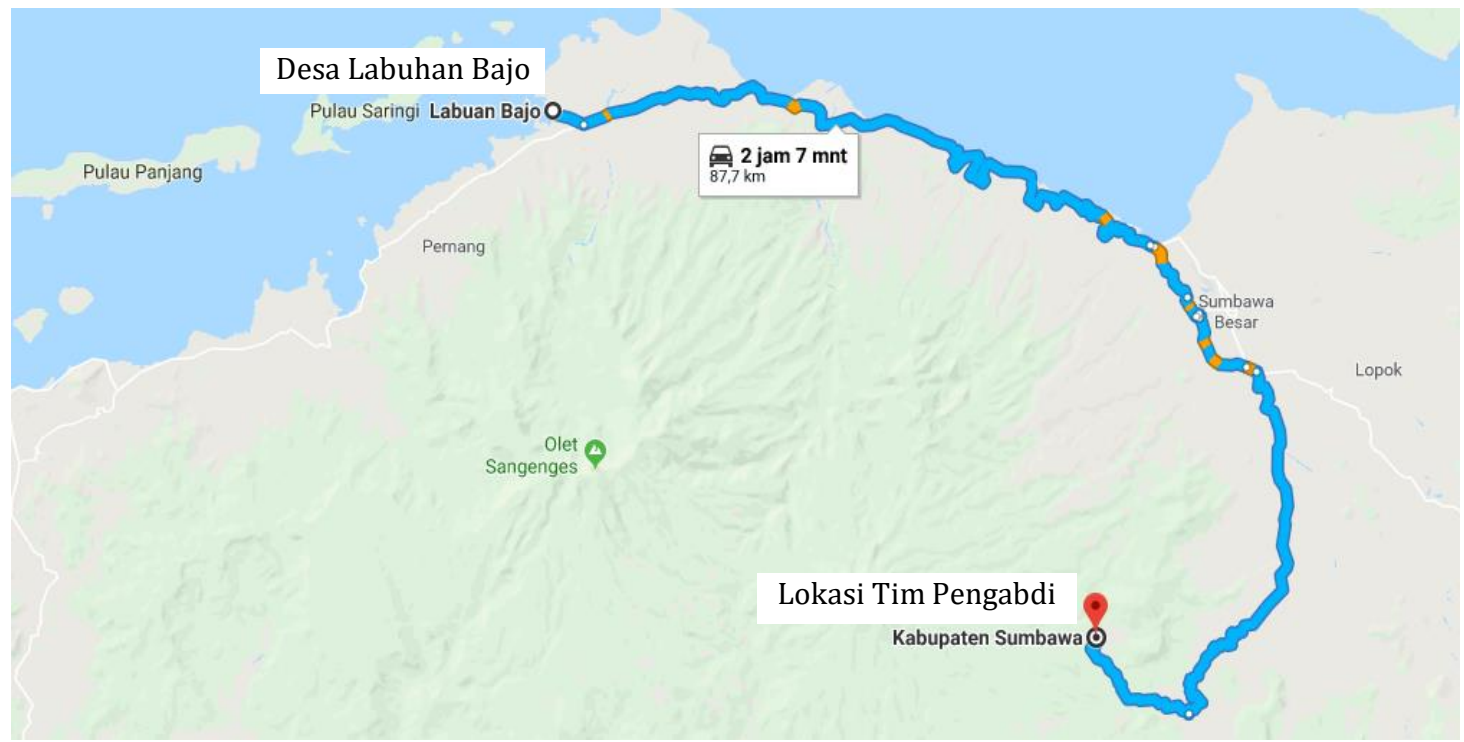

Gambar 1 Peta lokasi kegiatan pengabdian di Desa Labuhan Bajo.

mendapatkan bantuan iptek guna meningkatkan kuantitas dan kualitas garam yang mereka hasilkan. Kelompok Setia Kawan beranggotakan sebanyak 10 orang. Setiap anggota kelompok memiliki lahan garam yang digarap bersama dengan luasan rata-rata 20 are. Lahan tersebut berada pada satu lokasi dengan luasan \pm 2 ha. Pada lahan tambak telah terdapat satu gudang penyimpanan hasil produksi garam (Gambar 2) serta beberapa peralatan pendukung dalam produksi garam seperti mesin air, selang, pemadat meja garam, timbangan, dan karung.

\section{Tahapan Pelaksanaan Kegiatan}

Beberapa pendekatan yang dilakukan untuk mengatasi permasalahan mitra adalah 1) Participatory rural appraisal (PRA): suatu model pendekatan yang menekankan pada keterlibatan mitra dalam keseluruhan kegiatan mulai dari perencanaan, pelaksanaan, hingga evaluasi program kegiatan; 2) Participatory tecnology development: suatu model pendekatan yang memanfaatkan teknologi tepat guna berbasis ilmu pengetahuan dan kearifan budaya lokal; 3) Community development: suatu model pendekatan yang melibatkan mitra secara langsung baik sebagai subjek maupun objek pelaksanaan kegiatan pengabdian kepada masyarakat (Mardhia \& Alia 2018); 4) Persuasif: suatu model pendekatan yang bersifat himbauan dan dukungan tanpa unsur paksaan bagi mitra sehingga berperan aktif dalam kegiatan PPDM ini; dan 5) Edukatif: pendekatan melalui sosialisasi, pelatihan, dan pendampingan sebagai sarana transfer ilmu pengetahuan dan pendidikan untuk pemberdayaan mitra. Tahapan pelaksanaan
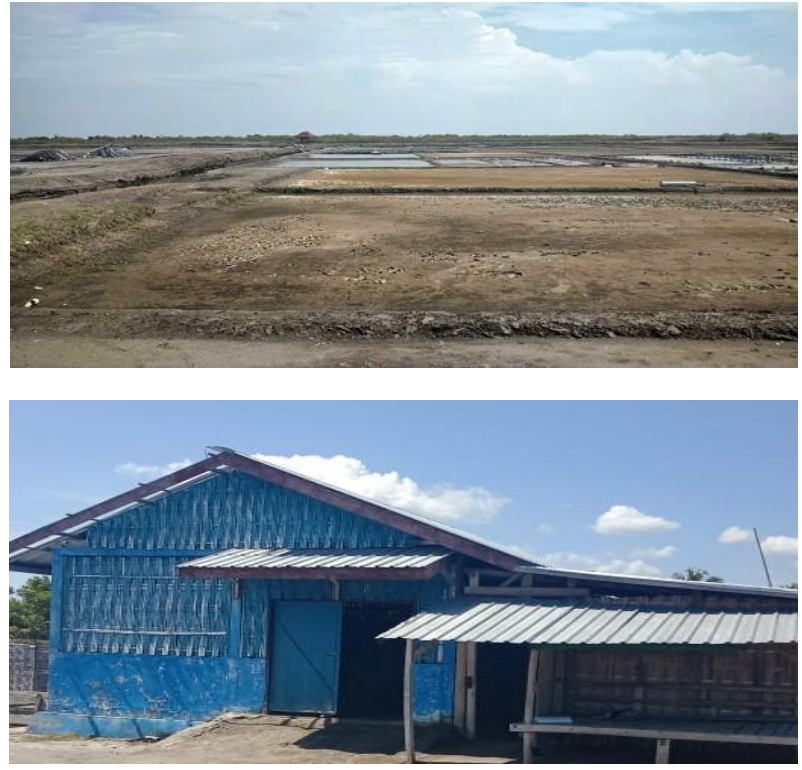

Gambar 2 Kondisi tambak dan gudang Kelompok Setia Kawan.

kegiatan terdiri dari sosialisasi dan koordinasi, persiapan kegiatan, penyuluhan dan pelatihan pembuatan garam beryodium, bantuan alat produksi, serta pendampingan.

\section{- Sosialisasi dan koordinasi}

Memberikan informasi dan arahan kepada kelompok Setia Kawan tentang pelaksanaan kegiatan dan luaran yang ingin dicapai serta penguatan komitmen kelompok dalam menyukseskan kegiatan PPDM.

\section{- Persiapan kegiatan}

Meliputi identifikasi dan persiapan kebutuhan kagiatan PPDM mulai dari tahap persiapan, pelaksanaan hingga monitoring dan evaluasi 


\section{- Penyuluhan dan pelatihan pembuatan garam beryodium}

Materi yang disampaikan saat penyuluhan untuk kelompok Setia Kawan adalah: 1) Potensi pengembangan industri maritim di Desa Labuhan Bajo; 2) Materi teknis peningkatan kualitas dan kapasitas produksi garam; 3) Peluang dan potensi ekonomi dari produksi garam beryodium; 4) Pentingnya mengonsumsi garam beryodium dalam rangka mengurangi angka kejadian GAKY khususnya stunting; dan 5) Pentingnya kelembagaan/kelompok usaha garam. Pelatihan dilakukan oleh trainer yang merupakan pelaku usaha garam beryodium.

\section{- Bantuan alat produksi}

Bantuan alat produksi yang diberikan kepada kelompok Setia Kawan berupa alat dan bahan yang dibutuhkan untuk produksi garam beryodium meliputi 1) Geoisolator untuk kristalisasi garam pada meja garam dalam meningkatkan kuantitas dan kualitas garam; 2) $\mathrm{KIO}_{3}$ untuk bahan iodisasi garam; 3) Mikser garam untuk mengaduk dan mencampur garam dengan $\mathrm{KIO}_{3}$; 4) Timbangan digital untuk menimbang $\mathrm{KIO}_{3}$; 5) Gelas ukur untuk mengukur volume campuran $\mathrm{KIO}_{3}$ 6) Bak besar untuk wadah garam; dan 7) Sprayer untuk menyemprot $\mathrm{KIO}_{3}$.

\section{- Pendampingan}

Pendampingan dalam hal produksi garam beryodium, manajemen usaha, pengemasan produk yang baik, dan pemasaran produk dengan cara yang lebih efektif dan efisien.

\section{- Monitoring dan evaluasi kegiatan}

Dilakukan untuk mengukur tingkat keberhasilan kegiatan PPDM yang dilaksanakan di Desa Labuhan Bajo pada tiap tahapan pelaksanaan kegiatan dan evaluasi secara menyeluruh pelaksanaan kegiatan dilakukan di setiap akhir tahun pelaksanaan kegiatan.

\section{HASIL DAN PEMBAHASAN}

\section{Sosialisasi dan Koordinasi}

Sosialisisasi dan koordinasi dilakukan kepada Pemerintah Kecamatan Utan, Pemerintah Desa Labuhan Bajo, dan Kelompok Setia Kawan (Gambar 3). Hasil yang diperoleh dari kegiatan sosialisasi dan koordinasi ini adalah pemerintah Kecamatan Utan dan Desa Labuhan Bajo menerima dan memberi dukungan terhadap rencana perwujudan Desa Labuhan Bajo sebagai desa garam beryodium melalui pemberdayaan Kelompok Setia Kawan. Dukungan tersebut dibuktikan dengan adanya kesepakatan fasilitasi lokasi kegiatan. Koordinasi dan sosialisasi kepada Kelompok Setia Kawan menghasilkan beberapa kesepakatan sebagai antara lain komitmen mengikuti kegiatan hingga akhir, melakukan peningkatan produksi garam yang berkualitas dan beryodium, memasarkan garam dan ikut mensosialisasikan kepada masyarakat akan pentingnya mengonsumsi garam beryodium.

\section{Persiapan Kegiatan}

Tim PPDM melakukan rapat koordinasi pembagian tugas untuk setiap pelaksanaan kegiatan dan mempersiapkan hal-hal yang dibutuhkan untuk mendukung kelancaran kegiatan termasuk persiapan alat dan bahan (Gambar 4).

\section{Penyuluhan}

Kegiatan penyuluhan dilaksanakan pada tanggal 25 Mei 2019. Kegiatan ini dihadiri oleh kelompok Setia Kawan, Dinas Perikanan dan Kelautan, Dinas Kesehatan, Pemerintah Desa Labuhan Bajo, Perwakilan Ibu-ibu PKK, dan Komunitas Kabete. Jumlah peserta kegiatan tersebut sebanyak 21 orang. Tujuan kegiatan ini adalah untuk memberikan edukasi dan meningkatkan kesadaran peserta tentang garam beryodium, potensi usaha garam beryodium yang dapat meningkatkan pendapatan masya-

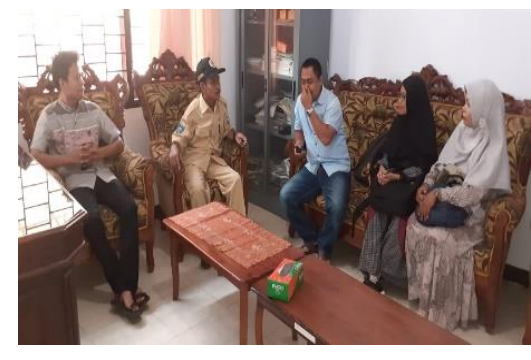

a

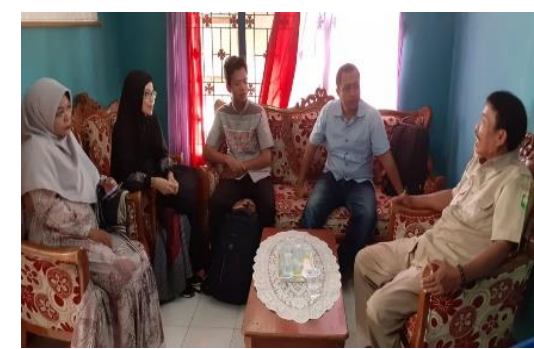

b

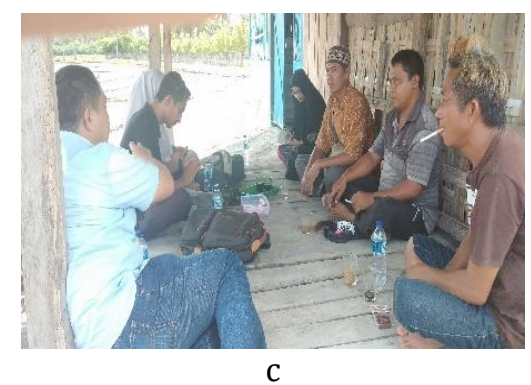

Gambar 3 Sosialisasi dan koordinasi dengan (a) Pemerintah Kecamatan Utan; (b) Pemerinta Desa Labuhan Bajo; dan (c) Kelompok Setia Kawan. 


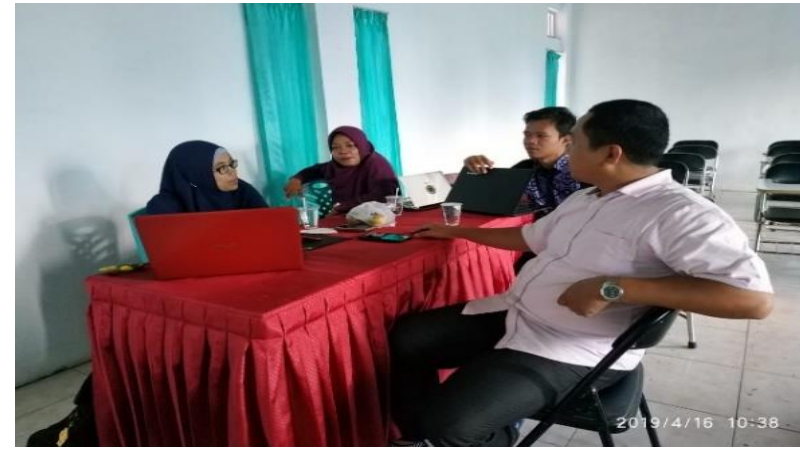

a

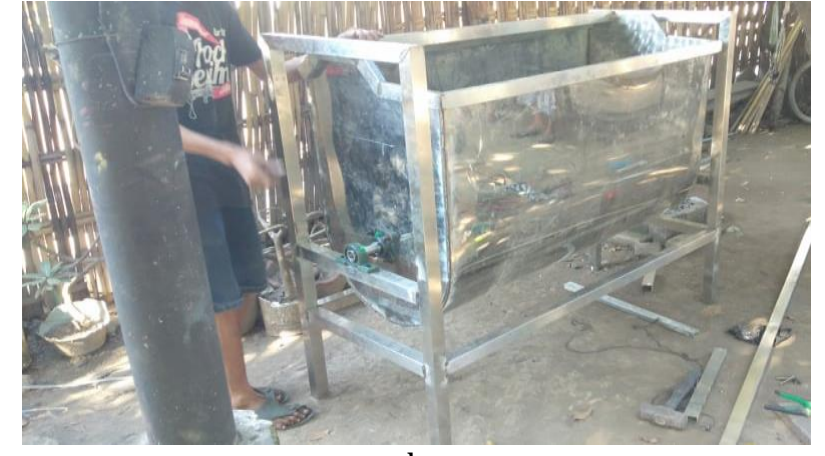

b

Gambar 4 a) Koordinasi tim program pengembangan desa mitra dan b) Persiapan alat dan bahan.

rakat yang ikut berkontribusi pada peningkatan derajat kesehatan masyarakat secara luas dan mencegah terjadinya GAKY. Pelaksanaan kegiatan penyuluhan terlihat pada Gambar 5.

Indikasi keberhasilan kegiatan penyuluhan diukur dari tingkat kehadiran peserta, antusias peserta mengikuti kegiatan dari awal hingga akhir serta hasil penilaian pengetahuan peserta berdasarkan analisis kuesioner yang diberikan melalui pre-test dan post-test. Hasil kegiatan penyuluhan menunjukkan hal-hal sebagai berikut:

- Jumlah kehadiran peserta sesuai dengan yang diharapkan, semua yang diundang hadir pada pelaksanaan kegiatan penyuluhan. Tingkat kehadiran peserta sebanyak $100 \%$. Peserta juga sangat antusias mengikuti kegiatan hingga akhir dan aktif bertanya saat sesi diskusi dan tanya jawab.

- Pengetahuan peserta terhadap materi penyuluhan dapat dilihat berdasarkan nilai pretest dan post-test pada Tabel 1. Nilai rata-rata pre-test adalah sebanyak 46 sedangkan posttest adalah sebanyak 85. Nilai tertinggi untuk pre-test adalah sebesar 78 dan terendah sebesar 17. Nilai tertinggi untuk post-tes adalah sebesar 100 dan nilai terendah sebesar 61 . Dari hasil tersebut terlihat adanya peningkatan penge-tahuan peserta tentang garam beryodium meliputi definisi, dampak kekurangan dan kelebihan yodium, cara penyimpanan dan cara memasak dengan garam yodium, kandungan garam beryodium, standar garam yodium garam konsumsi dan cara mengecek garam beryodium.

\section{Pelatihan Produksi Garam dengan Metode Teknologi Ulir Filter dan Iodisasi}

Pelatihan ini bertujuan untuk mengajarkan kelompok Setia Kawan bagaimana cara meningkatkan kualitas dan kuantitas garam serta cara memproduksi garam beryodium. Metode yang digunakan untuk meningkatkan kualitas dan

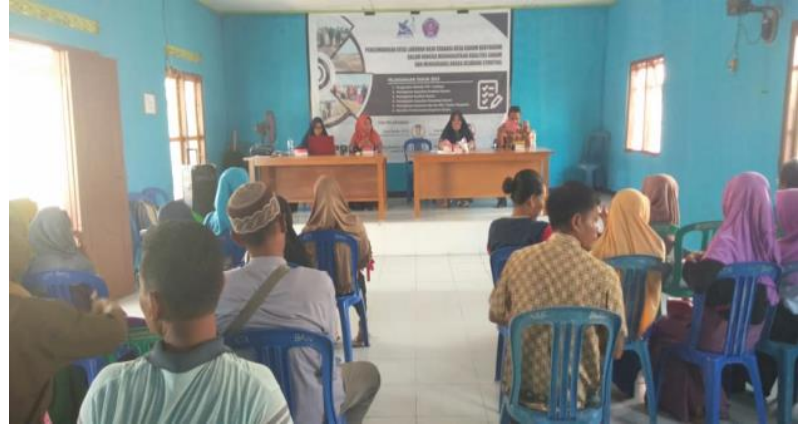

Gambar 5 Kegiatan Penyuluhan.

Tabel 1 Hasil pre-test dan post-test

\begin{tabular}{cccc}
\hline Responden & $\begin{array}{c}\text { Nilai } \\
\text { pre-test }\end{array}$ & $\begin{array}{c}\text { Nilai } \\
\text { post-test }\end{array}$ & Peningkatan \\
\hline 1 & 28 & 89 & 61 \\
2 & 56 & 78 & 22 \\
3 & 44 & 94 & 50 \\
4 & 61 & 78 & 17 \\
5 & 56 & 83 & 28 \\
6 & 56 & 94 & 39 \\
7 & 33 & 89 & 56 \\
8 & 22 & 72 & 50 \\
9 & 33 & 78 & 44 \\
10 & 22 & 83 & 61 \\
11 & 50 & 94 & 44 \\
12 & 50 & 89 & 39 \\
13 & 17 & 89 & 72 \\
14 & 67 & 89 & 22 \\
15 & 50 & 89 & 39 \\
16 & 67 & 100 & 33 \\
17 & 33 & 72 & 39 \\
18 & 78 & 94 & 17 \\
19 & 33 & 61 & 28 \\
20 & 72 & 94 & 22 \\
21 & 44 & 67 & 22 \\
\hline Rata-rata & 46 & 85 & 38 \\
\hline
\end{tabular}

Sumber: Data primer diolah, 2019

kuantitas garam adalah dengan sistem teknologi ulir filter (TUF) dengan media isolator. Menurut Adi \& Muhajir (2015) prinsip sistem TUF adalah pertama, adanya petak ulir yang diletakkan di antara petak tandon dan petak pinihan/jarangan 
yang berfungsi untuk menyaring kotoran dan mengendapkan unsur-unsur kimia yang ada dalam air laut seperti kalsium (Ca), magnesium $(\mathrm{Mg})$, dan sulfat $\left(\mathrm{SO}_{4}\right)$, serta meningkatkan kadar air dari 3 Be menjadi 8-10 Be melalui proses penguapan. Tujuan penggunaan filter adalah untuk menyaring air yang masuk dan keluar dari setiap petakan menjadi bersih sehingga garam yang dihasilkan berwarna putih bersih. Kedua, pemasangan media isolator pada meja garam dengan tujuan melapisi permukaan meja garam supaya dalam proses kristalisasi tidak bersentuhan langsung dengan tanah, sehingga mempercepat proses kristalisasi, mempercepat proses pembuatan garam, serta mempersingkat dan mempermudah pekerjaan panen garam. Kelebihan penggunaan isolator adalah tidak adanya perbaikan permukaan meja garam setelah panen, sehingga pembuatan garam berikutnya dapat dilakukan secara langsung tanpa meratakan permukaan meja garam. Kondisi inilah yang menyebabkan hasil panen garam TUF dengan media isolator lebih banyak dari cara tradisional. Penelitian yang dilakukan oleh Pranowo \& Muhajir (2015) menunjukkan bahwa pembuatan garam dengan sistem TUF dengan media isolator dapat meningkatkan produktifitas, kualitas, dan harga garam di Pati. Adapun proses pembuatan garam metode TUF terlihat pada Gambar 6.

Kegiatan pelatihan pembuatan garam beryodium dilakukan oleh trainer yang merupakan pelaku usaha garam beryodium. Tujuan mendatangkan trainer tersebut agar kelompok diajarkan langsung oleh orang yang memang sudah lama bergelut pada usaha garam beryodium. Metode iodisasi garam yang diajarkan adalah menggunakan metode basah kering

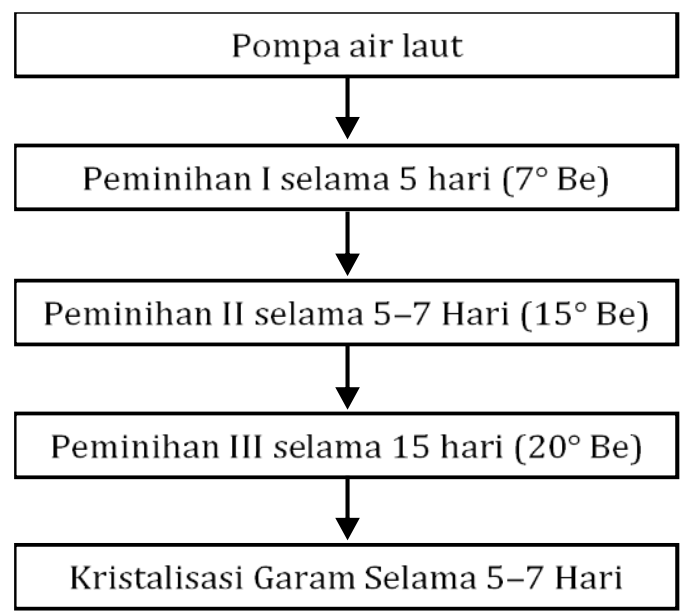

Gambar 6 Proses pembuatan garam metode teknologi ulir filter (TUF). (pencampuran padat cair). Pada proses ini garam dicampur dengan cairan yang mengandung iodium dengan cara diteteskan atau disemprotkan. Cara ini lebih menjamin homogenisasi hasil, tetapi kandungan air dalam garam akan bertambah (Hartati et al. 2014). Kelompok diajarkan cara menentukan komposisi yang tepat untuk $\mathrm{KIO}_{3}$ dan garam, serta cara mengencerkan $\mathrm{KIO}_{3}$, prosesnya yaitu garam ditimbang sebanyak 5 g dan dilarutkan dengan air suling, lalu ditambahkan dengan larutan KI (10\%). Selain itu, kelompok juga diajarkan cara pengemasan garam, analisis ekonomi usaha garam beryodium, pengenalan alat produksi, pengurusan izin usaha, dan cara memasarkan garam beryodium. Hasil kegiatan pelatihan adalah peserta memahami dan bisa mempraktikkan metode TUF dan iodisasi. Gambar 7 menunjukkan kegiatan pelatihan pembuatan garam beryodium.

\section{Bantuan Alat dan Produksi Garam dengan Metode Teknologi Ulir Filter dan Iodisasi}

Bantuan alat produksi yang diberikan kepada kelompok Setia Kawan berupa alat dan bahan yang dibutuhkan untuk produksi garam beryodium seperti terlihat pada Tabel 2 . Metode TUF dan iodisasi yang diterapkan pada produksi garam Kelompok Setia Kawan menghasilkan adanya peningkatan kualitas dan kuantitas produksi garam (Gambar 8). Hasil panen garam sebelum penerapan metode TUF adalah sebanyak 650 karung dengan bobot per karung
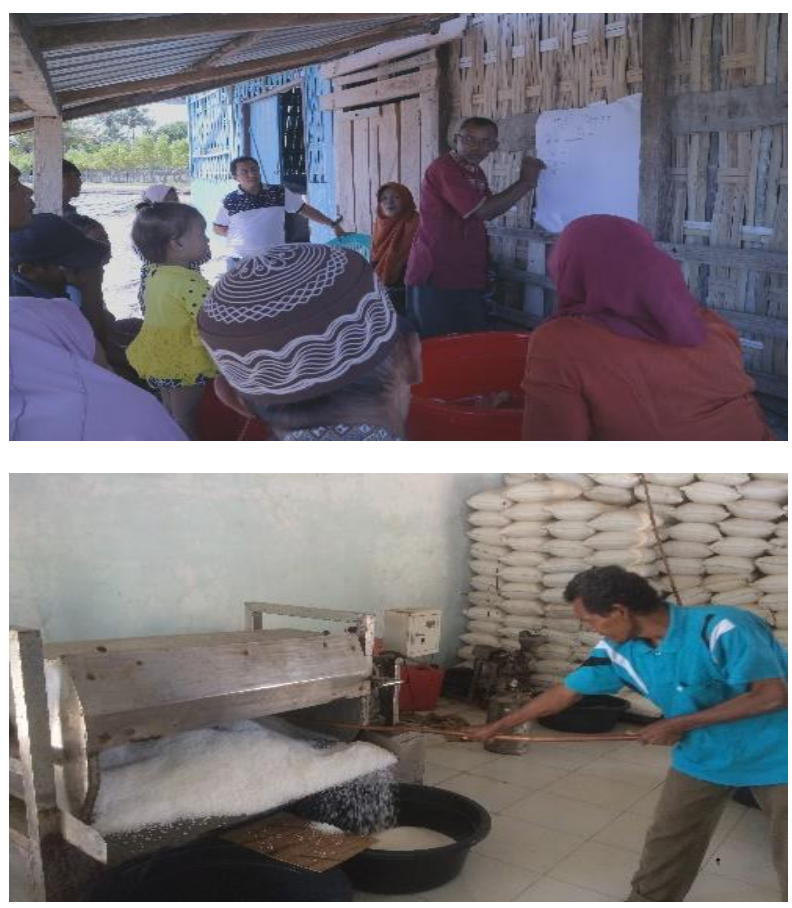

Gambar 7 Kegiatan pelatihan pembuatan garam beryodium. 
Tabel 2 Bantuan alat kepada kelompok Setia Kawan

\begin{tabular}{llc}
\hline \multicolumn{1}{c}{ Nama alat } & \multicolumn{1}{c}{ Spesifikasi } & Jumlah \\
\hline Geoisolator & Ukuran per roll $42 \times 4,4 \mathrm{~m}$ & $6 \mathrm{roll}$ \\
$\mathrm{KIO}_{3}$ & Bentuk white crystalline powder & $2 \mathrm{~kg}$ \\
Mikser garam & Tipe pencampuran dengan spray manual dengan dimensi panjang, lebar, & 1 unit \\
& dan tinggi: 250, 120, dan $150 \mathrm{~cm}$ & \\
Timbangan digital & Tingkat koreksi 0,01 & 1 unit \\
Gelas ukur & Silinder volume $100 \mathrm{~mL}$ & 2 unit \\
Bak besar & Bak plastik diameter $80 \mathrm{~cm}$ & 5 unit \\
Sprayer & Sprayer palstik volume $60 \mathrm{~mL}$ & $2 \mathrm{buah}$ \\
\hline
\end{tabular}

Sumber: Data primer diolah, 2019

$50 \mathrm{~kg}$, setelah penerapan metode TUF dengan isolator terjadi peningkatan produksi menjadi 967 karung. Kualitas garam juga menunjukkan kondisi fisik yang lebih baik, dibuktikan dengan warna yang semakin putih bersih. Produksi garam beryodium yang dihasilkan kelompok memiliki kadar yodium sesuai dengan persyaratan, yaitu berada pada kisaran 30-80 ppm. Hal ini sesuai dengan persayaratan SNI bahwa garam yang sampai ke konsumen harus memiliki kadar yodium sebesar 30-80 ppm (Amanati 2017).

\section{Monitoring dan Evaluasi}

Evaluasi pelaksanaan PPDM dilakukan pada beberapa hal sebagai berikut:

- Penilaian tingkat partisipasi mitra, dilakukan dengan cara memonitoring dan mengevaluasi jumlah kehadiran serta antusias mitra dalam setiap pelaksanaan kegiatan penyuluhan dan pelatihan. Selain itu, juga menilai dan mengevaluasi keberhasilan dalam setiap luaran kegiatan. Hasil evaluasi menunjukkan bahwa $100 \%$ mitra hadir sesuai permintaan jumlah peserta dan mereka mengikuti kegiatan hingga akhir. Kelompok Setia Kawan menunjukkan komitmen kuatnya sesuai dengan kesepakatan dengan tim PPDM, jumlah produksi garam mereka mengalami peningkatan sebanyak 317 karung dengan kualitas garam juga meningkat mencapai kualitas garam KW 1, pembuatan garam beryodium terus dilakukan dan kualitas garam beryodium sudah memenuhi syarat, yaitu sebesar 30-80 ppm. Produksi garam beryodium akan terus dimonitoring pada pelaksanaan tahun berikutnya.

- Penilaian tingkat pengetahuan mitra. Hasil penilaian menunjukkan adanya peningkatan pengetahuan mitra berdasarkan analisis pretest dan post-tes, yaitu rata-rata peningkatan sebesar 38\%.

- Penilaian tingkat keterampilan mitra. Setelah kegiatan pelatihan pembuatan garam ber-

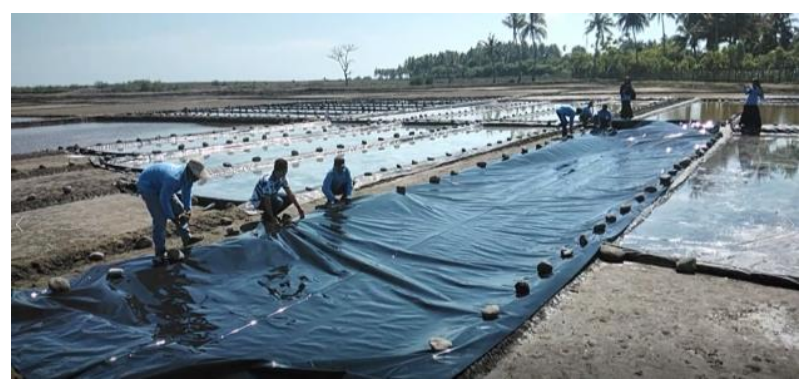

Gambar 8 Penerapan metode teknologi ulir filter dengan isolator.

yodium mitra PPDM sudah terampil dalam menghitung komposisi garam dan larutan $\mathrm{KIO}_{3}$, terampil dalam mengoperasikan mesin mikser garam, terampil dalam mengemas garam beryodium dan terampil dalam menggunakan media online dalam memperkenalkan kepada publik garam beryodium hasil produksi mereka yang diberi merek garam "MJ". Pemberian nama garam MJ adalah diambil dari nama dua penggagas pembentuk kelompok Setia Kawan, yaitu Marzuki dan Jumari. Jika dilihat persentase keterampilan bisa mencapai sebesar $70 \%$ artinya 7 dari 10 orang anggota kelompok sudah masuk kategori terampil.

- Evaluasi keberhasilan program secara menyeluruh: dilakukan dengan melihat beberapa indikator keberhasilan, yaitu 1) Adanya peningkatan jumlah produksi garam mencapai 317 karung; 2) Adanya peningkatan kualitas garam menjadi garam KW 1;3) Adanya garam beryodium; 4) Adanya peningkatan jumlah masyarakat yang mengkonsumsi garam beryodium berdasarkan hasil wawancara terhadap peserta penyuluhan yang sebelumnya tidak mengonsumsi garam beryodium kemudian mengkonsumsi garam beryodium dengan persentase sebesar $22 \%$ atau 4 dari 18 orang responden; dan 5) Adanya peningkatan pendapatan Kelompok Setia Kawan dari penjualan garam krosok yang semula harganya Rp 800 menjadi Rp 2.000 ditambah penjualan 
garam beryodium yang dijual Rp 2.500/kemasan $250 \mathrm{~g}$.

- Potensi keberlajutan program adalah dengan adanya pemberitaan melalui media massa dan video yang diupload melalui yuotube memperluas informasi terkait produksi garam beryodium oleh mitra dan mampu mendorong masyarakat lebih luas untuk mengonsumsi garam beryodium. Selain itu, produksi garam beryodium menjadi usaha yang dapat meningkatkan penghasilan usaha sehingga kelompok garam dapat meningkatkan pendapatannya. Peningkatan pendapatan secara otomatis dapat meningkatkan kesejahteraan dan status sosial mitra.

\section{SIMPULAN}

Kegiatan pengabdian kepada masyarakat ini telah mampu meningkatkan hasil produksi garam kelompok Setia Kawan. Kuantitas garam meningkat sebanyak 317 karung, dan kualitas garam juga meningkat dari KW 2 menjadi KW 1. Kelompok juga sudah mampu memproduksi garam beryodium, terampil dalam setiap tahapan pembuatan garam beryodium. Keberadaan garam beryodium kelompok Setia Kawan dengan nama garam "MJ" telah hadir untuk memenuhi kebutuhan masyarakat khususnya masyarakat di Desa Labuhan Bajo yang telah mampu memberi pengaruh berupa peningkatan pengetahuan dan kesadaran masyarakat untuk mengonsumsi garam beryodium. Kegiatan PPDM di tahun kedua lebih diprioritaskan pada pengurusan izin usaha kelompok dalam memproduksi garam beryodium sehingga mencapai pangsa pasar yang lebih luas.

\section{UCAPAN TERIMA KASIH}

Tim PPDM mengucapkan terima kasih kepada Dirjen Pendidikan Tinggi (DIKTI) yang telah memercayai dan membiayai kegiatan pengabdian kepada kelompok petani garam Setia Kawan di Desa Labuhan Bajo, Kecamatan Utan, Kabupaten Sumbawa. Penulis juga mengucapkan terima kasih kepada Lembaga Penelitian dan Pengabdian Masyarakat (LPPM) Universitas Samawa dan Pemerintah Desa Labuhan Bajo yang telah memfasilitasi kegiatan ini sehingga dapat terlaksana dengan baik

\section{DAFTAR PUSTAKA}

Amanati L. 2017. Karakteristik Kandungan KIO3 pada Garam Konsumsi Beryodium yang Beredar di Kota Blitar. Jurnal Teknologi Proses dan Inovasi Industri. 2(2): 67-70. https://doi.org/10.36048/jtpii.v2i2.3506

Hartati R, Supriyo E, Zanuri M. 2014. Yodisasi Garam Rakyat dengan Sistem Screw Injection. Gtech Jurnal Gema Teknologi. 17(4): 160-163. https://doi.org/10.14710/gt.v17i4.8935

Hidayat R, Syafikri D. 2014. PUGAR (Pemberdayaan Usaha Garam Rakyat) Kabupaten Sumbawa 2011-2016. Sumbawa (ID): Dinas Kelautan dan Perikanan Kabupaten Sumbawa Press.

Mardhia, Dwi., dan Alia Wartiningsih, 2018, Pelatihan Pengolahan Sampah Skala Rumah Tangga di Desa Penyaring, Jurnal Pendidikan dan Pengabdian Masyarakat UNRAM. 1(1): 88-96.

Pranowo SA, Muhajir. 2015. Dukungan Klinik Iptek Mina Bisnis (Kimbis) pada Program Pemberdayaan Usaha Garam Rakyat (PUGAR) di Kabupaten Pati. Buletin Ilmiah "MARINA" Sosial Ekonomi Kelautan dan Perikanan. 1(1): 19-28. https://doi.org/10.15578/marina. v1i1.1024

Rositawati AL, Taslim CM, Soetrinanto D. 2013. Rekristalisasi Garam Rakyat dari Daerah Demak untuk Mencapai SNI Garam Industri. Jurnal Teknologi Kimia dan Industri. 2(4): 217-225.

Syafikri D. 2016. Potensi Pengembangan Industri Garam di Kabupaten Sumbawa. Disampaikan pada kegiatan Penguatan Kelembagaan PUGAR. Sumbawa (ID): Pusat Kajian Pesisir dan Laut, Universitas Samawa.

Setiawan E, Machmud R, Masrul. 2018. Faktorfaktor yang berhubungan dengan kejadian stunting pada anak usia 24-59 bulan di wilayah kerja Puskesmas Andalas Kecamatan Padang Timur Kota Padang Tahun 2018. Jurnal Kesehatan Andalas. 7(2): 275-284. https://doi.org/10.25077/jka.v7.i2.p275284.2018 